\title{
The poverty of manner categories in motion verbs coding vertical relations. Evidence from Polish and Russian
}

\author{
Отсутствие категорий образа действия в глаголах движения, \\ кодирующих вертикальные отношения. На примере \\ польского и русского языков
}

\author{
Joanna Kozińska ${ }^{1}$
}

Accepted: 15 August 2020 / Published online: 30 March 2021

(C) The Author(s) 2021

\begin{abstract}
The article discusses the ways in which lexicalization of vertical motion takes place in two satellite-framed languages: Polish and Russian. In this typological category the manner of motion is typically rendered by the verb. The analysis of the descriptions of motion events by native speakers of these two genetically related languages shows that the lexicalization pattern of vertical motion differs from the horizontal one. First of all, when describing vertical relations, respondents less frequently code the manner of motion in the verb than when talking about motion along the horizontal plane. What is more, the results show that both Russian and Polish respondents use more motion verbs to describe vertical than horizontal relations, which points to the natural human tendency to code novel situations.
\end{abstract}

Аннотация В статье обсуждаются способы лексикализации вертикального перемещения в двух имеющих общую основу языках: польском и русском. В этой типологической категории способ перемещения обычно передается глаголом. Анализ описаний событий перемещения носителями этих двух генетически родственных языков показывает, что модель лексикализации вертикального перемещения отличается от горизонтального. Во-первых, респонденты при описании вертикальных отношений реже кодируют способ перемещения в глаголе, чем когда говорят о перемещении по горизонтальной плоскости. Кроме того, результаты показывают, что русские и польские респонденты для описания вертикальных отношений используют больше глаголов движения, чем для описания горизонтальных отношений, что указывает на естественную человеческую склонность кодировать новые ситуации.

\section{Introduction}

The article discusses the lexicalization patterns of vertical and horizontal motion in two genetically related languages: Polish and Russian. More specifically, the study concentrates on

\footnotetext{
J. Lozińska

joanna.lozinska@uwm.edu.pl

1 University of Warmia and Mazury in Olsztyn, Olsztyn, Poland
} 
the semantic components of manner included in the verbs encoding vertical motion and compares them to those included in the verbs which lexicalize horizontal motion. The topic is worth researching for two major reasons.

First of all, the lexicalization of vertical motion has been neglected in studies to date since it is a non-canonical direction of movement for the majority of animate beings, including humans. Consequently, on an everyday basis, it is coded far less frequently, and, according to the estimates based on the descriptions of motion events included in Polish novels, it amounts to no more than $6 \%$ of the total descriptions of motion relations (Lozińska 2018, p. 148). The research of vertical motion in some non-Slavic languages (e.g. Naigles et al. 1998) and Slavic languages (e.g. Filipović 2007; Łozińska and Pietrewicz 2018) specifies that the strategies of expressing vertical relations diverge from those used for horizontal ones. For example, Spanish in the typology of Talmy (2000) is a typical verb-framed language, which means that motion verbs express the path of motion and the coding of manner is peripheral and optional. However, Naigles et al.'s study shows that vertical motion events in Spanish tend to be expressed by means of manner verbs, which suggests that the lexicalization of vertical motion in this language diverges from the horizontal one. Nevertheless, the authors do not provide a clear answer as to why "the change in plane, in and of itself, might prompt speakers to talk about the manner of motion rather than the path" (Naigles et al. 1998, p. 542). As far as studies including Slavic languages are concerned, the study of three satellite-framed languages, namely Polish, Russian and English (Lozińska and Pietrewicz 2018), shows that in all these languages vertical relations were significantly more frequently expressed by path verbs when compared with horizontal ones. Finally, Filipović (2007, p. 128) in her analysis of motion in Serbo-Croatian notes a number of restrictions in this language when motion along the vertical scale is to be expressed.

The second reason for conducting research on the lexicalization of motion in Polish and Russian is that cross-linguistic studies of Slavic manner verbs are scarce and no unified model for the description of manner components conflated in Slavic motion verbs exists (but see Łozińska 2018). It is important to differentiate the semantic categories of manner in Slavic verbs of motion since it has been shown that they may differ from those distinguished on the basis of languages in which the domain of motion has been most intensively studied (e.g. English or Spanish). For example, the semantic component of axiological charge assigned to certain Polish and Russian motion verbs seems to have been neglected in motion studies to date (but see Łozińska and Góralczyk 2017).

From a perceptual point of view vertical motion events are different from horizontal ones in one major respect. Vertical motion of animate entities is unusual, and, consequently, does not occur as frequently on an everyday basis. As the previous studies have shown, it is natural for human beings to pay more attention to novel or unfamiliar stimuli than to usual or familiar ones. For example, in experimental studies adults have been shown to spend more time looking at novel slides than at familiar ones (McKee and Squire 1993). On this basis, I advance the first hypothesis (H1) that in the present study more attention will be paid to vertical motion situations by respondents and, as a result, this type of motion will be coded more frequently than the horizontal one.

What is more, the previous study of the lexicalization of vertical motion (Lozińska and Pietrewicz 2018) showed that respondents use more path verbs for coding vertical motion than for describing spatial relations along the horizontal axis. Since it is the direction of movement, in other words an element of the path, rather than the manner that is an extraordinary and thus more salient component of motion in the case of verticality, I advance the second hypothesis that the descriptions of motion along the vertical plane will be poorer in the description of manner of motion when compared with the descriptions of horizontal motion (H2). 
Finally, since the expected differences in the lexicalization of the two types of motion depend on the universal cognitive factors of all human beings rather than on the intricacies of spoken language, the third hypothesis (H3) is that the Polish and Russian respondents will similarly be more reluctant to code the manner of motion in the case of vertical than in the case of horizontal motion.

Before the analysis proper is offered, a brief overview of the ways in which spatial relations can be rendered in Polish and Russian will be presented (Sect. 2), as well as a classification of manner as a component of motion (Sect. 3).

\section{Lexicalization of motion in Polish and Russian-an overview}

In the typology of Talmy (2000) Slavic languages belong to the satellite-framed category. Such languages typically code the manner of motion in the verb, while the path is coded by means of satellites to the verb. Satellites in Polish and Russian are mainly verbal prefixes, which in the interaction with prepositional phrases render a vast array of spatial relations. This is illustrated by Talmy based on Russian (2000, pp. 105-106):

(1) Some path expressions in Russian

$$
\begin{aligned}
& \text { F... } \leftarrow \mathrm{v}-v+\mathrm{ACC}>\text { 'into' } \\
& \text { F. . } \leftarrow v y-i z+\text { GEN }>\text { 'out of' } \\
& \text { F... } \leftarrow \text { pere- čerez }+ \text { ACC }>\text { 'across' } \\
& \text { F... } \leftarrow \text { pod-pod }+ \text { ACC }>\text { 'to under' } \\
& \text { F... } \leftarrow \text { pod }-k+\text { DAT }>\text { 'up to' } \\
& \text { F... } \leftarrow o b-o b+\mathrm{ACC}>\text { 'to against' } \\
& \text { F... } \leftarrow \text { ot }-o t+\text { GEN }>\text { 'of a ways from' } \\
& \text { F... } \leftarrow n a-n a+\text { ACC }>\text { 'onto' } \\
& \text { F. . } \leftarrow s-s+\text { GEN }>\text { 'off of' } \\
& \text { F. . } \leftarrow \text { pro- mimo }+ \text { GEN }>\text { 'past' } \\
& \text { F... } \leftarrow z a-z a+\text { ACC }>\text { 'to behind/ beyond' } \\
& \text { F... } \leftarrow \text { pri- } k+\text { DAT }>\text { 'into arrival at' } \\
& \text { F. } . \leftarrow d o-d o+\text { GEN }>\text { 'all the way to' } \\
& \text { F. . } \leftarrow i z-i z+\text { GEN }>\text { '(issuing) forth from' }
\end{aligned}
$$

The sentences in (2) and (3) exemplify how translational motion is typically expressed in Polish and Russian respectively. While the verbs Pl iść 'to walk' and Ru idti 'to walk' conflate the manner (which in this case is the bipedal movement of body parts), the combination of prepositional phrases and verbal prefixes express the path:

(2) On wszedł do domu.

he in-went to house

'He went into a house.'

(3) On vošel v dom.

$\mathrm{He}$ in-went in house

'He went into a house.'

In both languages under study the prefixes have a perfectivizing function, nevertheless, these are not semantically empty lexical items (cf. Janda et al. 2013) and each of them carries a number of additional meanings. Spatial senses of the Polish and Russian prefixes are the most prototypical and transparent. To illustrate, the prefixes Ru $v$-and $\mathrm{Pl} w$-mark a figure's 
entering a container, cf. (2), (3), while Ru vy- and Pl wy-code the opposite relation, e.g. Pl Wyszedt z domu / Ru Vyšel iz doma '[He] went out of the house'.

Manner, which in Polish and Russian is typically rendered by means of motion verbs, characterizes how a figure moves. This includes various body movements as well as other semantic dimensions such as velocity of motion, a figure's effort or emotional state. Section 3 briefly reviews previous attempts to classify the manner of motion. The discussed categories of manner have been proposed by Levin (1993) for English motion verbs, Ibarretxe-Antuñano (2006) for Basque sound symbolic motion verbs and Cardini (2008) for Italian verbs.

\section{The classification of manner}

Levin (1993, p. 264) distinguishes the following categories of English motion verbs:

i. Roll verbs including such verbs as bounce, drift, drop, float, glide, move, roll, slide, swing. These verbs characterize the motion typical of inanimate entities;

ii. Run verbs with verbs like clamber, climb, crawl, creep, dash, fly, gallop, hop, jump, leap, skip, sleepwalk, stroll, swim, typically describing the ways in which animate entities can move;

iii. Verbs that are vehicle names, for example balloon, bicycle, bike, boat, bobsled, bus;

iv. Verbs that are not vehicle names, for example cruise, drive, fly, oar, paddle, pedal, ride, row, referring to motion carried out within or whilst riding a vehicle but are not related to the name of the vehicle.

In the classification of manner of motion proposed by Ibarretxe-Antuñano (2006) for Basque verbs the categories are more detailed than those differentiated by Levin (1993). First of all, Ibarretxe-Antuñano (2006) distinguishes a large semantic category of motor pattern. The additional categories which are not included in Levin's account (1993) include smooth motion, e.g. to roll, obstructed motion, e.g. to crash, furtive motion, e.g. to creep, forced motion, to drag, rate (speed of motion, which may be fast or slow) and inner state of the figure (referring to a figure's physical or psychological state).

Let us now summarize Cardini's (2008) analysis of the semantic components of manner of Italian motion verbs. The first group of semantic components coded in verbs of motion includes information about the aspects of motion directly referring to input material perceived by our senses. These are, for example, the physical characteristics of the figure or of the underlying surface, e.g. to roll, to bounce, or to slide, as well as verbs with information about body movements causing translational motion, e.g. to walk or to trot. This category also encompasses verbs which carry information about vehicles used for translational motion, such as to cycle or to canoe and about the sound associated with translational motion, such as to rattle or to whistle. Let me mention that Polish and Russian verbs rarely code the use of specific vehicles or the sound associated with motion. In both languages there is a frequently used hyperonym $\mathrm{Pl}$ jechać, Ru exat', which typically encompasses all types of motion by means of vehicles.

The second broad category differentiated by Cardini (2008) involves verbs carrying information about aspects of motion evoking fundamental concepts, such as speed, energy / force, weight, effort, continuity, steadiness (e.g. to speed or to trudge). Finally, the third group of verbs conflates aspects of motion denoting the emotional state of the figure motivating the way the figure moves (e.g. to hurry or to sneak).

As mentioned before, as far as Slavic languages are concerned, the previous analysis (Lozińska and Góralczyk 2017) of manner coded in Polish motion verbs reveals a semantic 
component supposedly not noted in previous studies of motion, which is the speaker's either positive or negative attitude towards one of the components of the described motion event. Some Polish and some Russian verbs express the speaker's negative assessment of a figure's manner of motion which may be clumsy, e.g. Pl gramolić się 'to scramble', or too slow, e.g. $\mathrm{Pl}$ wlec sie 'to drag on'. The negative assessment may also involve an undesired goal of motion or even a lack of it, e.g. Pl szlajać sie 'to loaf about' or Pl szwendać się 'to loiter' or $\mathrm{Ru}$ šljat'sja 'to loaf about'. There are also verbs which express a negative (e.g. Pl toczyć się 'to roll' about an obese person) or positive (e.g. Pl kroczyć 'to strut') attitude towards the moving figure itself.

Finally, as Ibarretxe-Antuñano (2006, p. 507) and Cardini (2008, p. 546) rightly point out, one lexical item may encapsulate more than one semantic component. To illustrate, the English verb limp codes both the motor movement of body parts as well as effort expended by the figure. What is more, one motion verb may conflate manner with the semantic component of path. For example, the verb climb codes the upward movement and motor pattern of body parts. It is noteworthy that a large number of Slavic verbs used to describe vertical relations code a few semantic components, referring to both path and manner of motion. This is the case with a large number of Polish and Russian verbs of motion, such as Pl wspinać się 'to climb', which codes the semantic component of upward movement as well as the use of limbs (cf. Łozińska and Pietrewicz 2018).

\section{Description of the study}

Recent recommendations in the field of cognitive linguistics point to the importance of quantitative studies (e.g. Janda 2013). The data used for the analysis in the present study come from elicitation tasks, which makes them particularly useful since they are close to everyday, colloquial speech and most accurately reflect the characteristic patterns of the lexicalization of motion. According to Talmy (1985, p. 62) 'characteristic' expression of motion means that: "(i.) It is colloquial in style, rather than literary, stilted, etc. (ii.) It is frequent in occurrence in speech, rather than only occasional. (iii.) It is pervasive, rather than limited, that is, a wide range of semantic notions are expressed in this type".

The aim of the present study is to compare the lexicalization patterns of vertical and horizontal motion in Polish and English. Let us recall that the prediction is that the description of motion situations elicited from the respondents will include more motion verbs coding vertical spatial relations than verbs used for the description of horizontal ones (H1). What is more, motion verbs used for the description of vertical relations will express the manner of motion less frequently than verbs describing horizontal relations will do (H2). Finally, no differences between Polish and Russian data are expected in both these respects (H3).

\subsection{Participants}

The survey was conducted in two groups of native speakers of Polish and Russian. Each group consisted of 20 respondents. They were of various ages ranging from 25 to 40 . There was no predominant level of education. In both groups women prevailed.

\subsection{Procedure}

Every participant was interviewed individually. The participants were asked to watch a compilation of twelve cartoons. After each episode a black screen appeared for 20 seconds and at that point the respondents were asked to write a description of the scene. 


\subsection{Stimuli}

The set of stimuli consisted of twelve cartoons of several-second length showing characters in motion and presenting a variety of manners of motion.

The descriptions of the stimuli provided in the following list are schematic since the scenes could be described in a number of ways. The motion verb chosen for the lexicalization of a given scene may code a variety of paths or manners of motion, which is why the generic verb to move is used. The first six scenes depicted vertical motion and the next six horizontal:

i. The figure moves down from a cliff.

ii. The figure moves up a tree.

iii. The figure moves up in the air and moves into the cylinder.

iv. The figure moves down in the air.

v. The figure moves up in the air and down into the snow.

vi. The figures move down the stairs.

vii. The figure moves around the tree and into it.

viii. The figure moves into a hollow of a tree.

ix. The figure moves in the air horizontally.

$\mathrm{x}$. The figure moves on the ground horizontally.

xi. The figure moves out of the house.

xii. The figure gets out of bed and moves across the room.

\subsection{Coding criteria}

The verbs classified as motion verbs meet the following criteria. Firstly, all of them denote translational motion "in which the location of the [f]igure changes in the time period under consideration" (Talmy 2000, p. 25). Secondly, all of them are intransitive. What is more, the reflexive forms of the verbs (such as Pl wbic się 'to break through'), which in the studied languages frequently express translational motion, were also included in the analysis.

\subsection{Results}

The discrepancy in the frequency of the usage of motion verbs that code horizontal and vertical relations is presented in Fig. $1 .^{1}$

Fig. 1 Number of motion verbs used for describing horizontal and vertical motion in Polish (black bars) and in Russian (white bars) in percentages

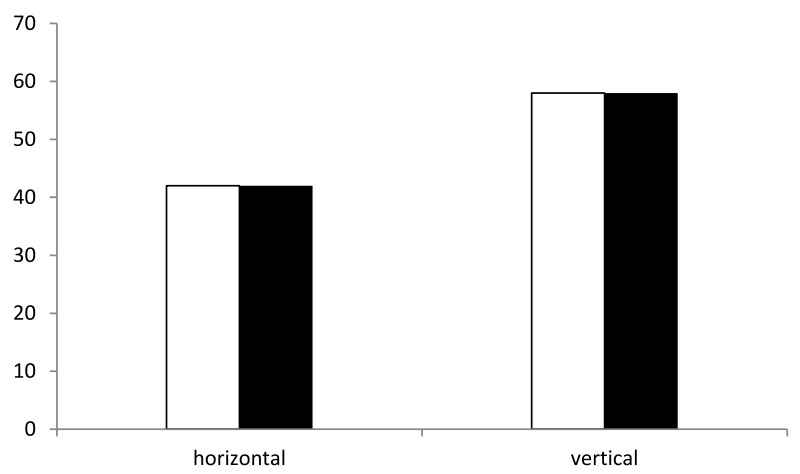

\footnotetext{
${ }^{1}$ For the raw data see Table 5 in Appendix.
} 
Fig. 2 Semantic components of manner conflated in Polish motion verbs used to describe horizontal (black bars) and vertical relations (white bars) in percentages
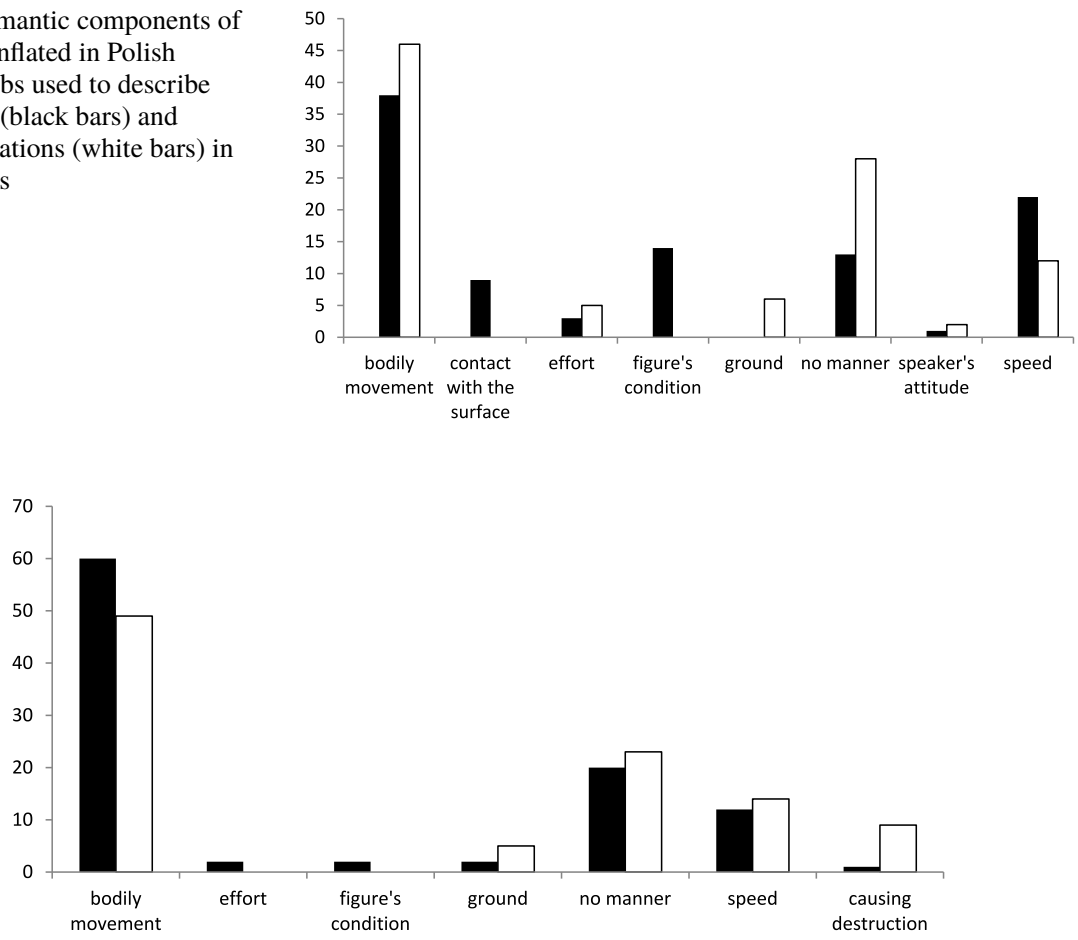

Fig. 3 Semantic components of manner conflated in Russian motion verbs used to describe horizontal (black bars) and vertical relations (white bars) in percentages

In both Polish and Russian, the percentages of the use of motion verbs for vertical (58\%) and horizontal (42\%) motion were identical. The results presented in Fig. 1 confirm the first hypothesis (H1) that vertical motion situations, less frequently observed in everyday life, attract more attention and, when observed, are more frequently coded. At the same time this observation also confirms the third hypothesis (H3) that the tendency to pay attention to less frequent phenomena is linguistically independent, which is why there are no differences between Polish and Russian data in this respect.

Figures 2 and 3 present the semantic components of manner conflated in the selected motion verbs as well as verbs without a manner component (marked as 'no manner') in Polish and Russian respectively.

In both languages, in the group of motion verbs with no component of manner, those that were used for coding vertical relations significantly outnumber the ones that were used for coding horizontal relations. What is more, the number of semantic components of manner included in the motion verbs describing vertical relations was significantly lower than in those describing horizontal relations (see Table 5 in Appendix). The differences approached a statistical significance for Polish $\left(\chi^{2}=2,7327,1542, d f=1, p=0,098\right)$ and were statistically significant for Russian $\left(\chi^{2}=8,7148, d f=1, p=0,03\right)$. These results confirm the second hypothesis (H2) that when it comes to vertical motion, verbs less frequently code the manner of motion when compared with verbs describing horizontal relations. What is more, the discrepancies in the manner categories used for coding the two directions of motion are similar in the two languages under study, which again confirms the third hypothesis (H3). 


\section{Qualitative analysis}

The qualitative analysis of the data will deal with the categories of manner verbs which were found to be most numerous. Tables 1,2,3, and 4 in the appendix show the ten most frequent types of verbs used by the respondents to describe the vertical and horizontal situations with the conflated manner categories. In case of doubt, the dictionary definitions were taken into consideration, however, the level of granularity as well as the fact that there may be a few semantic components included in one (single) verb complicated the task. What is more, the context of use of a given verb may considerably influence its semantic content. The group of verbs discussed in Sect. 5.3 referred to as 'no manner' encompasses verbs which do not code the manner of motion. This category mainly includes verbs expressing the path of motion.

\subsection{Numbers of tokens used for coding vertical and horizontal relations}

As shown in Fig. 1 the respondents of both languages used more motion verbs to describe vertical than horizontal relations although the same number of cartoons for each direction of motion was presented to them. In the case of horizontal spatial relations, the respondents more frequently paid attention to situations other than motion ones than was the case for vertical relations. In situation xi, for example, most of the respondents neglected the action of going out of a house by the figure and did not code it. Instead the respondents of both languages described what the figure did immediately after this action, as in (4):

(4) Wiewiórka w pośpiechu zamiata podłogę przed domem.

Squirrel in haste sweep. floor in.front.of house

'The squirrel is hastily sweeping the floor in front of the house.'

Similarly, in (5) it was not motion itself that was described but the figure's intention to hide in the burrow and in this way entering the burrow was not coded by means of a motion verb:

$$
\begin{aligned}
& \text { Myška sprjatalas' v duple. } \\
& \text { Mouse hid in burrow } \\
& \text { 'The mouse hid in the burrow.' }
\end{aligned}
$$

In case of vertical relations, motion was lexicalized in both Polish and Russian more frequently than in case of horzontal relations (see Fig. 1).

\subsection{Movement of body parts and speed}

Movement of body parts and speed were noted to be the most frequent semantic components rendered by means of the verb in both languages as far as horizontal and vertical motion is concerned. Since it is by means of movement of body parts that animate entities canonically change their location, the high frequency of this semantic component for both types of motion is not surprising. Example (6) illustrates the use of the verb skakać 'to jump', which commonly codes voluntary upward motion:

$$
\begin{aligned}
& \text { Królik skacze i zanurza się } \mathrm{w} \text { kapeluszu. } \\
& \text { Rabbit jumps and immerses REFL in hat } \\
& \text { 'A rabbit jumps and immerses in a hat.' }
\end{aligned}
$$

As already mentioned, some verbs may conflate a few semantic categories. To illustrate, the Polish verb piać się 'to climb' not only codes the use of limbs but at the same time an upward path of motion, as in (7): 
(7) Kojot wspina się na drzewo.

Coyote climbs REFL on tree

'The coyote is climbing a tree.'

Speed is another frequent manner of motion noted both for horizontal and vertical motion, incidentally it is often conflated with other manners, such as the movement of body parts. The verb 'to run' is the most frequent example.

The semantic components called 'causing destruction' and 'figure's effort' are typical of vertical movement. The group of verbs named 'causing destruction' encompasses verbs which typically denote a forceful downward motion accompanied by noise and destruction of the figure or of the ground. This includes verbs such as valit'sja (8) and ruxnut' (9), which in the present study were noted only in the Russian data:

(8) Slomalas' vetka i kojot svalilsja s dereva.

break.PST.SG.F branch and coyote fell from tree

'A branch broke and the coyote forcefully fell from the tree.'

(9) Ruxnul vniz.

fall.PsT.SG.M down

'He fell down forcefully.'

A figure's effort (usually connected with overcoming the gravity) is another manner of motion typically coded for verticality, which is illustrated in (10):

(10) Zwierz wdrapuje się na drzewo.

Animal scrambles REFL on tree

'An animal is climbing a tree.'

\subsection{No manner category}

As shown in Figs. 2 and 3, verbs that do not code the manner of motion in both Polish and Russian data are more frequently noted in the descriptions of vertical motion. The most common verbs in this category include motion verbs denoting an involuntary downward motion such as padać 'to fall'. What is noteworthy is that the same situation may be coded as voluntary by means of a manner verb as in (11) or as an accidental (involuntary) motion without coding the manner as in (12):

$\begin{array}{lllll}\text { Sprygnul } & \mathrm{S} & \text { obryva } & \mathrm{v} & \text { reku. } \\ \text { down.jump.PST SG.M } & \text { from } & \text { cliff } & \text { in } & \text { river }\end{array}$

'He jumped down from the cliff into the river.'

$\begin{array}{lll}\text { Upal so skaly. } & \text { so } \\ \text { down.fall.pst.sg.m from } & \text { rock } \\ \text { 'He fell from the rock.' }\end{array}$

In both languages under study there is a large group of motion verbs that include both the path and manner component. This exceptional group mainly includes verbs that were created in the process of acquiring a prefix by non-verbal elements, for example Pl oddalić się 'to move away', or Pl zblizyć się 'to approach' (cf. Kopecka 2010) or in the process of the fusion of prefixes with verbs of motion into an inseparable whole, for example Pl wznosić sie 'to rise', Ru spuskat'sja 'to move down' (cf. Kopecka 2010; Speed 2015; Verkerk 2014, 2015). This type of verbs typically appears in the descriptions of vertical motion, as in (13) but can also appear in descriptions of forced motion that require a greater expenditure of energy, as in (14): 


\section{(13) Tolpa spustilas' s lestnicy. \\ crowd down.move.PST.SG.F from ladder \\ 'The crowd moved down the ladder.'}

(14) Tom leci przez pokój i wbija się w kominek.

Tom flies through room and in.beats REFL in chimney

'Tom flies through the room and breaks into the chimney.'

\section{Conclusions}

Polish and Russian belong to the satellite-framed languages, in which the motion verb typically codes the manner of motion. In contrast to this typical pattern, our study revealed that motion verbs used for the description of vertical motion less frequently code the manner of motion in comparison to those coding horizontal relations. What is more, although the numbers of horizontal and vertical motion situations represented in the stimuli were equal, the descriptions of vertical motion in both languages included significantly more motion verbs coding this type of relation, which points to the natural human tendency to pay attention to novel stimuli.

Publisher's Note Springer Nature remains neutral with regard to jurisdictional claims in published maps and institutional affiliations.

Open Access This article is licensed under a Creative Commons Attribution 4.0 International License, which permits use, sharing, adaptation, distribution and reproduction in any medium or format, as long as you give appropriate credit to the original author(s) and the source, provide a link to the Creative Commons licence, and indicate if changes were made. The images or other third party material in this article are included in the article's Creative Commons licence, unless indicated otherwise in a credit line to the material. If material is not included in the article's Creative Commons licence and your intended use is not permitted by statutory regulation or exceeds the permitted use, you will need to obtain permission directly from the copyright holder. To view a copy of this licence, visit http://creativecommons.org/licenses/by/4.0/.

\section{Appendix}

Table 1 Semantic components of manner ceded ten most frequent Russian motion verbs used for coding vertical relations

\begin{tabular}{lllllll}
\hline Types & Tokens & $\begin{array}{l}\text { Manner (M), } \\
\text { Path (P) }\end{array}$ & $\begin{array}{l}\text { Bodily } \\
\text { movement }\end{array}$ & Speed & $\begin{array}{l}\text { Figure's } \\
\text { effort }\end{array}$ & $\begin{array}{l}\text { Ground } \\
\text { Destructive } \\
\text { motion }\end{array}$ \\
\hline $\begin{array}{l}\text { prygat' 'to jump' } \\
\text { past' 'to fall' }\end{array}$ & 30 & $\mathrm{M}$ & $\checkmark$ & & \\
$\begin{array}{l}\text { bežat' 'to run' } \\
\text { lezt' 'to walk up' }\end{array}$ & 14 & $\mathrm{P}$ & & & \\
$\begin{array}{l}\text { karabkat'sja 'to climb with } \\
\text { difficulty using limbs' }\end{array}$ & 10 & $\mathrm{M}$ & $\checkmark$ & $\checkmark$ & \\
$\begin{array}{l}\text { nyrjat' 'to dive' } \\
\text { (s)valit'sja 'to fall down }\end{array}$ & 6 & $\mathrm{P}+\mathrm{M}$ & $\checkmark$ & & \\
forcefully' & $\mathrm{P}+\mathrm{M}$ & $\checkmark$ & $\checkmark$ & \\
$\begin{array}{l}\text { vinčivat'sja/vvintit'sja } \\
\text { 'to screw in' }\end{array}$ & 5 & $\mathrm{P}+\mathrm{M}$ & & & $\checkmark$ & \\
$\begin{array}{l}\text { nestis' 'to speed' } \\
\text { ruxnut' 'to fall down } \\
\text { forcefully' }\end{array}$ & 4 & $\mathrm{P}$ & & & & \\
\hline
\end{tabular}


Table 2 Semantic components of manner coded in ten most frequent Russian motion verbs used for coding horizontal relations

\begin{tabular}{llllll}
\hline Types & Tokens & $\begin{array}{l}\text { Manner (M), } \\
\text { Path (P) }\end{array}$ & Bodily movement & Speed & $\begin{array}{c}\text { Ground } \\
\text { Figure's } \\
\text { condition }\end{array}$ \\
\hline bežat' 'to run' & 13 & $\mathrm{M}$ & $\checkmark$ & $\checkmark$ & \\
idti 'to walk' & 13 & $\mathrm{M}$ & $\checkmark$ & \\
letat' 'to fly' & 12 & $\mathrm{M}$ & $\checkmark$ & \\
lezt' 'to climb' & 10 & $\mathrm{P}+\mathrm{M}$ & $\checkmark$ & $\checkmark$ & $\checkmark$ \\
nestis' 'to speed' & 7 & $\mathrm{M}$ & & $\checkmark$ \\
jurknut' 'to escape quickly' & 4 & $\mathrm{P}+\mathrm{M}$ & & \\
mčat'sja 'to speed' & 4 & $\mathrm{M}$ & & \\
dvigat'sja 'to move' & 2 & 0 & & $\checkmark$ \\
lunatit' 'to sleepwalk' & 2 & $\mathrm{M}$ & & $\checkmark$ \\
nyrjat' 'to dive' & 2 & $\mathrm{P}+\mathrm{M}$ & & \\
\hline
\end{tabular}

Table 3 Semantic components of manner coded in ten most frequent Polish motion verbs used for coding vertical relations

\begin{tabular}{|c|c|c|c|c|c|c|}
\hline Types & Tokens & $\begin{array}{l}\text { Manner (M), } \\
\text { Path }(\mathrm{P})\end{array}$ & $\begin{array}{l}\text { Movement of } \\
\text { body parts }\end{array}$ & Speed & Figure's effort & Ground \\
\hline skakać 'to jump' & 40 & M & $\checkmark$ & & & \\
\hline padać 'to fall' & 37 & $\mathrm{P}$ & & & & \\
\hline biegać 'to run' & 18 & M & $\checkmark$ & $\checkmark$ & & \\
\hline wspinać się 'to climb' & 13 & $\mathrm{P}+\mathrm{M}$ & $\checkmark$ & & $\checkmark$ & \\
\hline nurkować 'to dive' & 9 & $\mathrm{P}+\mathrm{M}$ & & & & $\checkmark$ \\
\hline wdrapać się 'to climb' & 5 & $\mathrm{P}+\mathrm{M}$ & $\checkmark$ & & $\checkmark$ & \\
\hline wwiercać się 'to twist into' & 5 & $\mathrm{P}$ & & & & \\
\hline leźć 'to walk' & 4 & $\mathrm{M}$ & $\checkmark$ & & & \\
\hline pędzić 'to speed' & 3 & M & & $\checkmark$ & & \\
\hline uciekać 'to escape' & 3 & $\mathrm{P}$ & & & & \\
\hline
\end{tabular}

Table 4 Semantic components of manner in ten most frequent Polish motion verbs used for coding horizontal relations

\begin{tabular}{llllll}
\hline Types & Tokens & $\begin{array}{l}\text { Manner (M), } \\
\text { Path (P) }\end{array}$ & $\begin{array}{l}\text { Bodily } \\
\text { movement }\end{array}$ & $\begin{array}{l}\text { Speed } \\
\text { Figure's } \\
\text { effort }\end{array}$ & $\begin{array}{l}\text { Figure's } \\
\text { condition }\end{array}$ \\
\hline lunatykować 'to sleepwalk' & 20 & $\mathrm{M}$ & $\checkmark$ & $\checkmark$ \\
biegać 'to run' & 15 & $\mathrm{M}$ & & \\
uciekać 'to espcape' & 12 & $\mathrm{P}$ & $\checkmark$ & \\
iść 'to walk' & 12 & $\mathrm{M}$ & $\checkmark$ & \\
lecieć 'to fly' & 10 & $\mathrm{M}$ & & \\
pędzić 'to speed' & 10 & $\mathrm{M}$ & & \\
petznać 'to creep' & 8 & $\mathrm{P}+\mathrm{M}$ & $\checkmark$ & \\
skakać 'to jump' & 6 & $\mathrm{M}$ & $\checkmark$ & $\checkmark$ \\
mknać 'to move quickly' & 4 & $\mathrm{M}$ & & \\
kręcić się 'to spin' & 2 & $\mathrm{P}$ & & \\
\hline
\end{tabular}


Table 5 Tokens of verbs including at least one component of manner / total number of tokens

\begin{tabular}{lllll}
\hline & Vertical motion & $\%$ & Horizontal motion & $\%$ \\
\hline Russian & $93 / 123$ & 75,6 & $83 / 91$ & 91,2 \\
Polish & $103 / 159$ & 64,8 & $86 / 116$ & 74,1 \\
\hline
\end{tabular}

\section{References}

Cardini, F.-E. (2008). Manner of motion saliency: An inquiry into Italian. Cognitive Linguistics, 19(4), 533-569. https://doi.org/10.1515/COGL.2008.021.

Filipović, L. (2007). Talking about motion: A crosslinguistic investigation of lexicalization patterns (Studies in Language Companion Series, 91). Amsterdam, Philadelphia.

Ibarretxe-Antuñano, I. (2006). Ttipi-ttapa ttipi-ttapa... korrika!!! Motion and sound symbolism in Basque. Anuario del Seminario de Filología Vasca 'Julio de Urquijo', 40, 499-518.

Janda, L. A. (Ed.) (2013). Cognitive linguistics: The quantitative turn. The essential reader. Berlin.

Janda, L. A., Endresen, A., Kuznetsova, J., Lyashevskaya, O., Makarova, A., Nesset, T., \& Sokolova, S. (2013). Why Russian aspectual prefixes aren't empty: prefixes as verb classifiers. Bloomington.

Kopecka, A. (2010). Motion events in Polish: Lexicalization patterns and the description of Manner. In V. Hasko \& R. Perelmutter (Eds.), New approaches to Slavic verbs of motion (Studies in Language Companion Series, 115, pp. 225-246). Amsterdam, Philadelphia.

Levin, B. (1993). English verb classes and alternations. A preliminary investigation. Chicago.

Łozińska, J. (2018). Path and manner saliency in Polish in contrast with Russian. A cognitive linguistic study (Brill's Studies in Language, Cognition and Culture, 15). Leiden.

Łozińska, J., \& Góralczyk, I. (2017). Axiology of Polish motion verbs. A cognitive study. In A. Kiklewicz \& J. Piwowar (Eds.), Wartości i wartościowanie we wspótczesnej humanistyce. T. III: Perspektywa językoznawcza (pp. 73-81). Olsztyn.

Łozińska, J., \& Pietrewicz, B. (2018). Lexicalisation of vertical motion. A study of three satellite-framed languages. Cognitive Studies / Études cognitives, 18, 1-13. https://doi.org/10.11649/cs.1601.

McKee, R. D., \& Squire, L. R. (1993). On the development of declarative memory. Journal of Experimental Psychology: Learning, Memory, and Cognition, 19(2), 397-404.

Naigles, L. R., Eisenberg, A. R., Kako, E. T., Highter, M., \& McGraw, N. (1998). Speaking of motion: Verb use in English and Spanish. Language and Cognitive Processes, 13(5), 521-549. https://doi.org/10.1080/ 016909698386429.

Speed, T. (2015). Manner / path typology of Bulgarian motion verbs. Journal of Slavic Linguistics, 23(1), 51-81.

Talmy, L. (1985). Lexicalization patterns: Semantic structure in lexical forms. In T. Shopen (Ed.), Language typology and syntactic description. Volume III: Grammatical categories and the lexicon (pp. 57-149). New York.

Talmy, L. (2000). Toward a cognitive semantics. Volume II: Typology and process in concept structuring. Cambridge.

Verkerk, A. (2014). The evolutionary dynamics of motion event encoding. Doctoral dissertation, Radboud University Nijmegen. Enschede.

Verkerk, A. (2015). Where do all the motion verbs come from? The speed of development of manner verbs and path verbs in Indo-European. Diachronica, 32(1), 69-104. https://doi.org/10.1075/dia.32.1.03ver. 